\title{
IDENTIFIKASI BAKTERI PATOGEN (Vibrio spp. DAN Salmonella spp.) YANG MENGONTAMINASI IKAN LAYANG DAN BANDENG DI PASAR TRADISIONAL
}

\author{
Burhanuddin Ihsan \\ Program Studi Akuakultur, Fakultas Perikanan dan Ilmu Kelautan, Universitas Borneo Tarakan \\ Jalan Amal Lama No.1 Universitas Borneo Tarakan. Kec. Tarakan Timur. Kota Tarakan \\ Diterima: 18 Januari 2021/Disetujui: 30 April 2021 \\ *Korespondensi: ihsan.borneo16@borneo.ac.id
}

Cara sitasi: Ihsan B. 2021. Identifikasi bakteri patogen (Vibrio spp. dan Salmonella spp.) yang mengontaminasi ikan layang dan bandeng di pasar tradisional. Jurnal Pengolahan Hasil Perikanan Indonesia. 24(1): 89-96.

\begin{abstract}
Abstrak
Sumber konsumsi ikan masyarakat Kota Tarakan adalah ikan layang dan bandeng yang berasal dari pasar tradisional. Pengelolaan pasar tradisional yang ada di Kota Tarakan cukup memadai namun, tingkat kesehatan dan higienis lingkungan masih kurang baik, penanganan yang belum memadai memungkinkan banyak bakteri yang berkembang dan mengontaminasi ikan. Tujuan penelitian untuk mengetahui kontaminasi bakteri patogen (Vibrio spp. dan Salmonella spp.) pada ikan yang dijual di pasar tradisional kota Tarakan. Penelitian dilakukan dengan metode deskriptif dengan beberapa tahapan mulai dari observasi pasar, pengambilan sampel, isolasi bakteri dan identifikasi. Isolasi bakteri Vibrio menggunakan media selektif TCBS (Thiosulfate Citrate Bile Salt Sucrose) dan bakteri Salmonella menggunakan media SSA (Salmonella Shigella Agar) identifikasi bakteri Vibrio dan Salmonella yang berpedoman pada buku Bergey's Manual of Determinative Bacteriology berdasarkan sifat morfologi dan kimiawi. Hasil identifikasi terdapat kontaminasi bakteri Vibrio spp. dan Salmonella spp. pada hasil perikanan yang dijual di pasar tradisional kota Tarakan khususnya ikan bandeng dan ikan layang.
\end{abstract}

Kata Kunci: bakteri, ikan, isolasi, kontaminasi, Tarakan

\section{Identification of Pathogenic Bacteria Contamination (Vibrio spp. and Salmonella spp.) in Flying Fish and Milkfish in Traditional Markets}

\begin{abstract}
The sources of fish consumption for the people of Tarakan City are flying fish and milkfish from traditional markets. The management of traditional markets in Tarakan City is quite adequate, however, the level of health and hygiene of the environment is still not good, inadequate handling allows many bacteria to grow and contaminate fish. The research objective was to determine the contamination of pathogenic bacteria (Vibrio spp. and Salmonella spp.) at fish sold in traditional markets Tarakan City. The research was conducted using a descriptive method with several stages starting from market observation, sampling, isolation and identification of bacteria. Isolation of Vibrio bacteria using selective media TCBS (Thiosulfate Citrate Bile Salt Sucrose) and Salmonella bacteria using SSA media (Salmonella Shigella Agar). Identification of Vibrio spp. and Salmonella spp. based on Bergey's Manual of Determinative Bacteriology based on morphological and chemical properties. Identification results contaminated with Vibrio spp. and Salmonella spp. Fish products sold in traditional markets in Tarakan include milkfish and flying fish.
\end{abstract}

Keyword: bacterial, contamination, fish, isolate, Tarakan City 


\section{PENDAHULUAN}

Tarakan merupakan salah satu pulau yang terletak di Kalimantan bagian utara yang berbatasan langsung dengan laut Sulawesi dan memiliki potensi perikanan yang cukup tinggi khususnya ikan. Ikan merupakan salah satu potensi sumberdaya alam yang dapat dimanfaatkan dalam rangka meningkatkan kesejahteraan dan pasokan konsumsi bagi masyarakat. Ikan, udang, kepiting dan rumput laut memiliki nilai ekonomi dan ekspor yang sangat tinggi dibandingkan dengan organisme akuatik lainnya. Selain itu ikan juga menjadi pemasok kebutuhan protein hewani dalam rangka memenuhi kebutuhan dalam Negeri. (Asikin et al. 2014).

Salah satu sumber konsumsi ikan masyarakat Kota Tarakan adalah ikan layang dan bandeng yang berasal dari pasar tradisional. Pengelolaan pasar tradisional yang ada di kota Tarakan cukup memadai namun, tingkat kesehatan dan higienis lingkungan masih kurang baik, penanganan yang belum memadai memungkinkan banyak bakteri yang berkembang dan mengontaminasi ikan. Beberapa hasil perikanan yang terkontaminasi oleh bakteri patogen dapat menimbulkan dampak keracunan khususnya ikan kembung, tongkol, salem, dan siput dengan gejala mulai dari muntah, sakit kepala, dan badan lemas hingga beberapa korban meninggal dunia (Dwiyitno 2010).

Bakteri patogen merupakan bakteri yang dapat menyebabkan penyakit bagi inangnya dengan adanya perubahan jaringan melalui perubahan genetik (Suharni et al. 2008). Salah satu ciri dari bakteri patogen yaitu bersifat saprofit. Selain menyebabkan penyakit bakteri patogen juga dapat menurunkan dan mempengaruhi aspek kualitas serta kemunduran mutu produk perikanan. Beberapa bakteri yang sering mengontaminasi hasil perikanan di antaranya adalah bakteri Vibrio dan Salmonella. Penelitian dari Ihsan et al. 2018) menyatakan bahwa ikan bandeng yang dijual di pasar tradisional mengandung bakteri patogen khususnya bakteri Salmonella.

Bakteri Salmonella adalah bakteri patogen yang dapat menyebabkan penyakit bagi manusia maupun hewan budi daya.
Penyakit yang ditimbulkan jika manusia terinfeksi bakteri Salmonella adalah penyakit demam tifus pada manusia, yang menyebabkan demam tinggi dengan efek muntah-muntah. Sedangkan bakteri Vibrio adalah bakteri patogen yang hidup di perairan dan bersifat oportunistik serta dapat menyebabkan penyakit bagi manusia. Jenis bakteri Vibrio yang sering menginfeksi manusia diantaranya $V$. parahaemolyticus dan $V$. cholerae yang dapat menyebabkan penyakit vibriosis. Dengan demikian kontaminasi bakteri patogen harus diminimalisasi dengan pengelolaan hasil perikanan yang lebih baik, agar kontaminasi bakteri patogen yang ada di pasar tradisional di bawah ambang batas baku mutu kesehatan, dengan batas maksimum jumlah koloni bakteri pada hasil perikanan yang diperbolehkan untuk dikonsumsi adalah sebesar 5 x $10^{5}$ koloni/g (SNI 01-2729-2006).

Produk hasil perikanan khususnya ikan yang dikonsumsi harus aman dan sehat serta terhindar dari kontaminasi bakteri patogen. Hal ini harus menjadi perhatian dalam rangka menyiasati maraknya peredaran hasil perikanan yang kurang bermutu, mengandung bakteri patogen dan mengandung bahan kimia berbahaya yang dapat menyebabkan keracunan. Tujuan penelitian ini adalah untuk mengetahui kontaminasi bakteri patogen (Vibrio dan Salmonella) pada ikan bandeng dan ikan layang yang dijual di pasar tradisional kota Tarakan.

\section{BAHAN DAN METODE Bahan dan Alat}

Bahan yang digunakan dalam penelitian diantaranya ikan bandeng dan layang serta media selektif TCBS (Thiosulfate Citrate Bile Salt Sucrose), SSA (Salmonella Shigella Agar), TSIA (Triple Sugar Iron Agar), APW (Alkali Pepton Water), lactose broth, PCA (Plate Count Agar), pereaksi pewarnaan gram, glukosa, sukrosa dan akuades. Alat yang digunakan antara lain alat kaca (tabung reaksi, cawan petri, erlenmeyer, jarum ose, batang pengaduk dan bunsen), lemari pendingin, timbangan analitik, autoklaf dan hot plate, laminari air flow dan inkubator. 


\section{Pengambilan sampel}

Pengambilan sampel dilakukan pada saat air pasang tertinggi. Air pasang tertinggi merupakan waktu persediaan ikan di pasar melimpah. Sampel ikan layang dan bandeng yang telah diambil lalu dimasukkan ke dalam plastik steril lalu disimpan di dalam cool box yang berisi es, selanjutnya dibawa ke laboratorium untuk dianalisis mikrobiologinya (kurang dari satu jam setelah ikan tiba di laboratorium).

\section{Isolasi bakteri Vibrio}

Sampel ikan bandeng pada bagian kulit, daging, insang dan usus dicampur kemudian dihaluskan dengan menggunakan mortar dan sebanyak 20 g sampel diambil kemudian dimasukkan ke dalam erlenmeyer yang berisi media APW sebanyak $200 \mathrm{~mL}$, selanjutnya diinkubasi pada suhu ruang atau $30{ }^{\circ} \mathrm{C}$. Inokulum tersebut kemudian diambil dengan menggunakan jarum ose selanjutnya digores pada media TCBS. Selanjutnya diinkubasi pada suhu $30{ }^{\circ} \mathrm{C}$ atau suhu ruangan selama 24-48 jam, begitu pula pada sampel ikan layang. Koloni yang terpisah kemudian diamati morfologinya (warna, bentuk, elevasi, diameter dan tepi koloni) (Hidayat dan Syarif 2013).

\section{Isolasi bakteri Salmonella}

Sampel ikan bandeng pada bagian kulit, daging, insang, dan usus dicampur dan dihaluskan dengan menggunakan mortar kemudian sebanyak $25 \mathrm{~g}$ sampel dimasukkan kedalam erlenmeyer yang berisi $225 \mathrm{~mL}$ media lactose broth lalu dihomogenkan selama 2 menit. Kemudian inokulum tersebut diambil dengan menggunakan jarum ose lalu ditumbuhkan pada media SSA dengan metode streak plate. Selanjutnya diinkubasi pada suhu $37^{\circ} \mathrm{C}$ selama $24-48$ jam, begitu pula pada sampel ikan layang. Koloni yang terpisah kemudian diamati morfologinya (warna, bentuk, elevasi, diameter, dan tepi koloni) (SNI 01-2332.2-2006).

\section{Karakterisasi dan identifikasi}

Karakterisasi bakteri Vibrio dan Salmonella dilakukan dengan pengujian biokimia (uji oksidase, MIO, indol, O/F, fermentasi glukosa, $\mathrm{H}_{2} \mathrm{~S}$ TSIA dan katalase). Identifikasi bakteri Vibrio spp. dan Salmonella spp. berpedoman pada Bergey's Manual of Determinatif Bacteriology (Holt et al. 1994).

\section{HASIL DAN PEMBAHASAN Deskripsi Pasar Tradisional}

Hasil observasi dan pengamatan pasar tradisional (beringin) kota Tarakan berada di atas perairan dengan bangunan kayu yang disemenisasi, terlihat bahwa pengelolaan hasil perikanan khususnya ikan cukup baik berdasarkan tata letak dan pembagian tempat. Selain itu sanitasinya sangat memadai karena pembuangannya langsung mengarah pada perairan yang berada di bawah, walupun dapat mencemari perairan sekitar. Selain itu tempat penyimpanan ikan dengan stirofoam dan bak penampungan sesuai dengan standar pengelolaan pendaratan ikan dengan pemberian es secara merata (Figure 1)

Kontaminasi bakteri sangat dipengaruhi oleh pengelolaan pasar, jika pengelolaan pasar baik maka dapat mengurangi kontaminasi bakteri. Menurut Rene et al. 2014, pasar tradisional lebih mudah terkontaminasi oleh bakteri dibandingkan dengan pasar modern yang memiliki standardisasi lebih baik. Salah satu bentuk kontaminasi bakteri patogen

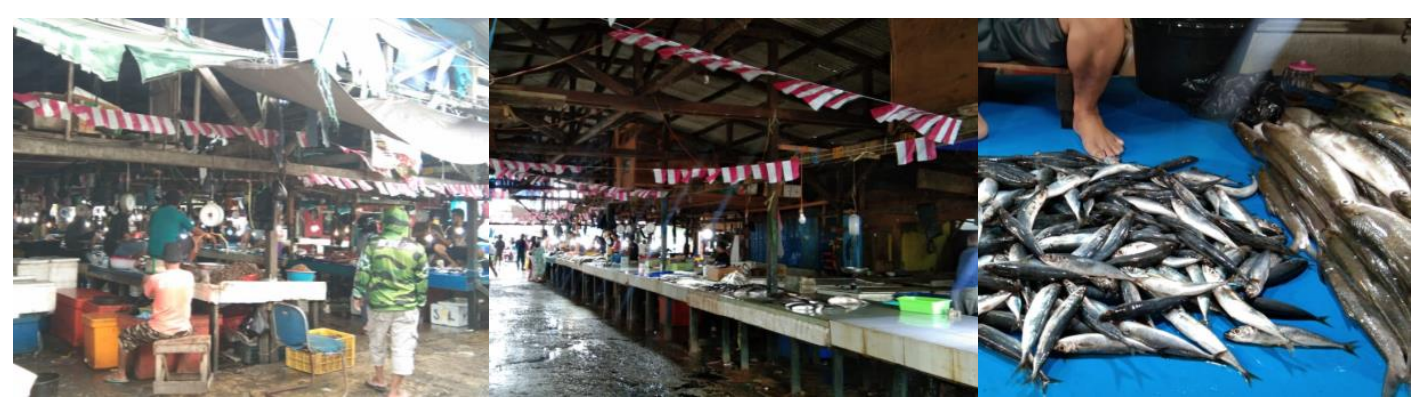

Figure 1 Beringin Traditional Market in Tarakan, North Borneo 
khususnya Salmonella pada pasar tradisional yaitu dengan berpindahnya lalat dan insekta, dari tempat sampah kemudian menghinggapi hasil perikanan yang dijual. Selain itu buruknya pengelolaan ikan juga memengaruhi kontaminasi bakteri dan kualitas kesegaran ikan mulai penanganan, penangkapan, distribusi, maupun selama penjualan. Sesuai dengan penelitian Suprayitno 2020 bahwa daerah penangkapan, penggunaan es sebagai pendingin, cara penyimpanan, suhu, cuaca dan penanganan pascapanen dapat memengaruhi kualitas kesegaran ikan. Observasi yang dilakukan terlihat bahwa ikan yang dijual di pasar tradisional masih segar berdasarkan morfologi penampakan atau pengamatan organoleptik yaitu warna bola mata cerah dan bening, bola mata menonjol, daging masih utuh, kenampakan segar dan mengilat, insang berwarna kemerahan dan tidak berlendir, bagian perut masih utuh, tekstur dagingnya padat jika ditekan tidak meninggalkan bekas serta baunya spesifik ikan segar.

\section{Isolasi Bakteri Vibrio}

Hasil isolasi bakteri pada ikan layang dan bandeng dengan menggunakan media pengkayaan APW, media ini berfungsi untuk meningkatkan atau menyuburkan bakteri agar pada saat dipindahkan ke media isolasi dapat tumbuh dengan baik. Media isolasi menggunakan media selektif TCBS, media ini mengandung tiosulfat yang mampu menghambat bakteri lain untuk tumbuh sehingga media ini hanya ditumbuhi oleh bakteri Vibrio saja. Sesuai dengan pendapat Ihsan dan Retnaningrum (2020) bahwa media selektifTCBS mampu menghambat bakterilain dengan kandungan tiosulfat selain itu media
TCBS tidak perlu disterilisasi menggunakan autoklaf karena dapat menghilangkan kandungan tiosulfat yang menjadi sifat selektif pada media TCBS. Isolat bakteri Vibrio memiliki ciri koloni; berwarna hijau dan kuning, tepi koloni mengutuh (entire), elevasi koloni conver dan bentuk koloni membundar (circular). Ciri tersebut memiliki kesesuaian dengan penelitian (Ihsan dan Retnaningrum 2017) dengan bentuk elevasi conver pada bagian morfologi koloni. Selain itu Handayani et al. (2020) menyatakan bahwa bakteri Vibrio memiliki ciri koloni; berwarna hijau dan kuning, bentuk koloni membundar, tepi koloni entire dan elevasi bersifat conver. Koloni bakteri yang didapatkan pada hasil penelitian berwarna kuning dan hijau, ini disebabkan oleh bakteri Vibrio yang dapat menurunkan $\mathrm{pH}$ serta mampu memfermentasi sukrosa pada media TCBS sehingga koloni bakteri berwarna kuning, sedangkan koloni yang berwarna hijau disebabkan tidak mampu memfermentasi sukrosa (Figure 2).

\section{Isolasi Bakteri Salmonella}

Isolasi bakteri Salmonella mengguakan media selektifSSA yaitu media yang digunakan khusus untuk menumbuhkan bakteri Salmonella dan Shigella. Kandungan selektif yang terdapat pada media SSA yang mampu menghambat bakteri lain yaitu bile salt dan brilliant green. Hasil isolasi bakteri Salmonella pada ikan bandeng dan layang terdapat ciriciri dengan koloni berwarna merah jambu (pink), bentuk koloni membundar baik yang berukuran besar maupun pada bagian elevasi berbentuk cembung (convex) dan mengutuh pada bagian tepi serta pada pertumbuhan lebih dari 24 jam koloni berwarna hitam

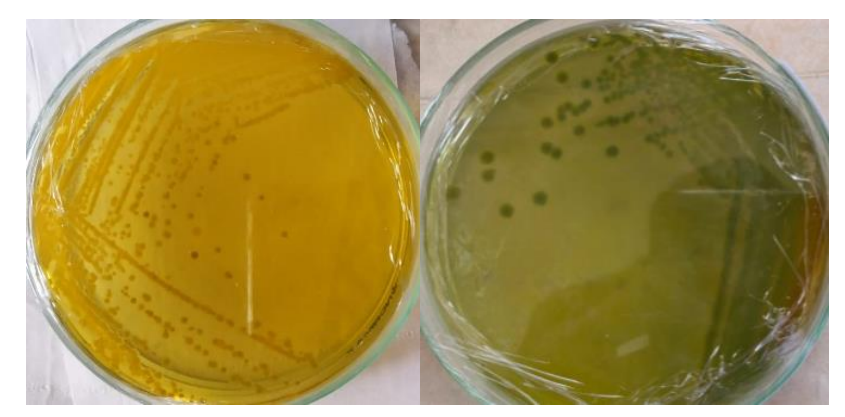

Figure 2 Isolate of Vibrio spp. 
yang dimulai pada bagian inti. Ciri tersebut memiliki kesamaan dengan penelitian Ihsan et al. (2018) bahwa koloni bakteri berwarna merah muda (pink) pada bagian inti berwarna hitam, berbentuk bulat dengan bagian tepi koloni bersifat mengutuh, elevasi berbentuk cembung, setelah diinkubasi selama 24-48 jam. Setelah diinkubasi selama lebih dari 72 jam, terdapat koloni bakteri berwarna hitam secara keseluruhan namun ada juga yang tidak berwarna hitam pada cawan petri yang lain (Figure 3 ).

\section{Karakterisasi (Uji Biokimia)}

Hasil isolasi bakteri kemudian dilakukan pewarnaan gram untuk mengetahui bakteri gram positif dan negatif serta bentuk sel bakteri, kemudian dilanjutkan dengan uji biokimia. Uji biokimia dilakukan berdasarkan buku identifikasi Bergey's Manual of Determinatif Bacteriology. Uji oksidase dilakukan untuk mengetahui adanya sitokrom oksidasi pada bakteri. Hasil uji oksidase pada semua isolat bakteri menunjukkan sifat positif dengan terjadinya perubahan warna pada kertas Oxidase Test Strip menjadi warna biru violet, perubahan warna yang terjadi disebabkan sitokrom oksidase mengoksidasi aminodimetilanilin oksalat. Pada uji katalase bersifat positif dengan adanya gas atau gelembung udara, hal tersebut terjadi karena adanya enzim katalase pada bakteri yang mampu mengubah $\mathrm{H}_{2} \mathrm{O}$ menjadi oksigen. Sedangkan uji motilitas bersifat positif pada isolat (A2 bandeng dan A2 layang) karena bakteri pada daerah tusukan terlihat menyebar, ini menandakan bahwa bakteri tersebut memiliki flagela yang dapat bergerak atau motil. Sedangkan pada isolat (A1 bandeng dan A1 layang) bersifat negatif karena tidak terlihat sebaran pada daerah tusukan dan media tidak keruh sehingga bakteri ini tidak memiliki flagela.

Hasil uji biokimia pada indol menunjukkan bahwa isolat bakteri tidak mampu membentuk lapisan cincin berwarna merah pada media, karena bakteri tersebut tidak mampu memanfaatkan indol sebagai sumber karbon sehingga uji indol bersifat negatif. Sedangkan uji fermentasi glukosa bersifat positif pada isolat (A2 bandeng dan A2 layang) disebabkan adanya perubahan warna pada media menjadi kuning. Sedangkan pada isolat (A1 bandeng dan A1 layang) bersifat negatif karena tidak ada perubahan warna. Uji O/F bersifat fermentatif pada isolat (A2 bandeng dan A2 layang) karena terjadi perubahan warna menjadi kuning namun tidak berubah warna pada media yang diberikan larutan parafin. Sedangkan isolat (A1 bandeng dan A1 layang) bersifat oksidatif karena tidak terjadi perubahan warna. Hasil pengujian $\mathrm{H}_{2} \mathrm{~S}$ dengan media TSIA semua isolat bersifat positif karena terjadi perubahan warna artinya semua isolat mampu memfermentasi gula dan membentuk $\mathrm{H}_{2} \mathrm{~S}$.

Hasil uji biokimia yang dihasilkan sesuai dengan penelitian (Ashofa et al. 2014) yang juga mengidentifikasi bakteri Vibrio pada kepiting dengan hasil oksidase, motilitas, indol $\mathrm{H}_{2} \mathrm{~S}$ (TSIA) dan katalase bersifat positif serta uji $\mathrm{O} / \mathrm{F}$ bersifat fermentatif. Selain itu pada penelitian pendapat (Austin and Austin 1989) bahwa bakteri Vibrio memiliki karakter kimiawi diantaranya oksidase dan katalase bersifat positif, mampu memfermentasi glukosa, reduktasi nitrat positif, bersifat

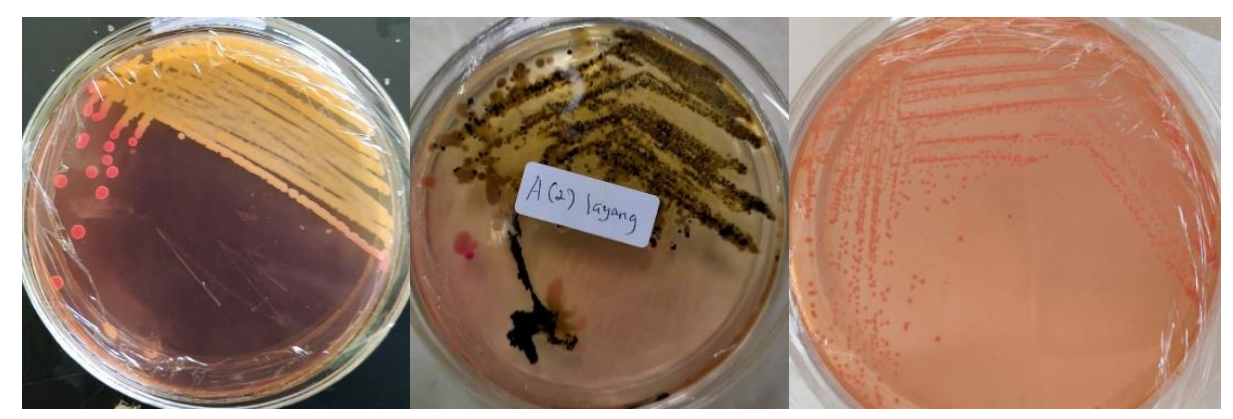

Figure 3. Salmonella bacterial isolate. 
fermentatif pada uji O/F dan bersifat positif pada motility disebabkan bakteri Vibrio memiliki flagela. Sedangkan pada penelitian (Rahmi et al. 2014) yang mengisolasi dan mengidentifikasi bakteri Salmonella pada feses orang utan juga memiliki kesamaan hasil dari uji biokimia dengan hasil fermentasi glukosa dan $\mathrm{H}_{2} \mathrm{~S}$ (TSIA) bersifat positif serta uji motilitas dan indol bersifat negatif. Pendapat tersebut juga diperkuat oleh. Amiruddin et al. (2017) yang menyatakan bahwa bakteri Salmonella memiliki karakter uji indol bersifat negatif, uji TSIA bersifat positif, dan tidak mampu melakukan fermentasi glukosa.

Secara keseluruhan hasil karakterisasi dan identifikasi bakteri Vibrio dan Salmonella dengan sifat morfologi dan biokimia dapat dilihat pada tabel (Table 1).

\section{Identifikasi Bakteri Patogen}

Hasil identifikasi berdasarkan sifat morfologi dan biokimia pada buku Bergey's
Manual of Determinative Bacteriology diketahui bahwa terdapat kontaminasi bakteri patogen (Vibrio spp. dan Salmonella spp.) pada ikan bandeng dan ikan layang yang dijual di pasar tradisional kota Tarakan. Isolat (A2 bandeng dan A2 layang) teridentifikasi sebagai bakteri Vibrio spp. dan isolat (A1 bandeng dan A1 layang) teridentifikasi sebagai bakteri Salmonella spp.

\section{Kontaminasi Bakteri Vibrio dan Salmonella}

Kontaminasi bakteri Vibrio spp. dan Salmonella spp. pada ikan bandeng dan layang yang dijual di pasar tradisional kota Tarakan diharapkan menjadi perhatian pemerintah dan masyarakat dalam pengelolaannya. Agar terhindar dari infeksi bakteri patogen pada ikan yang akan dikonsumsi maka ikan tersebut harus dibersihkan dan dimasak dengan baik sehingga terhindar dari infeksi bakteri patogen yang dapat menimbulkan penyakit. Infeksi

Table 1 Morphological and Biochemical Characteristics of Bacterial Isolate from Tarakan Traditional Market

\begin{tabular}{|c|c|c|c|c|}
\hline \multirow[b]{2}{*}{ Character } & \multicolumn{4}{|c|}{ Isolate } \\
\hline & A1 Layang & A2 Layang & $\begin{array}{c}\text { A1 } \\
\text { Bandeng }\end{array}$ & $\begin{array}{c}\text { A2 } \\
\text { Bandeng }\end{array}$ \\
\hline Circular & + & + & + & + \\
\hline Entire & + & + & + & + \\
\hline Convex & + & + & + & + \\
\hline Yellow colony color & & + & & \\
\hline Pink colony color & + & & + & \\
\hline Green colony color & & & & + \\
\hline Gram staining & - & - & - & - \\
\hline Rod-shape cell & & + & & + \\
\hline Circular-shape cell & + & & + & \\
\hline Catalase & + & + & + & + \\
\hline Oxidase & + & + & + & - \\
\hline Glucose fermentation & - & + & - & + \\
\hline $\mathrm{O} / \mathrm{F}$ & $\mathrm{O}$ & $\mathrm{F}$ & $\mathrm{O}$ & $\mathrm{F}$ \\
\hline $\mathrm{H}_{2} \mathrm{~S}$ Triple Sugar Iron (TSI) slant & + & + & + & + \\
\hline Motility & - & + & - & + \\
\hline Indol & - & - & - & - \\
\hline Identification & $\begin{array}{l}\text { Salmonella } \\
\text { spp. }\end{array}$ & Vibrio spp. & $\begin{array}{l}\text { Salmonella } \\
\text { spp. }\end{array}$ & Vibrio spp. \\
\hline
\end{tabular}

Note: $\mathrm{O}=$ oxidative; $\mathrm{F}=$ fermentative 
bakteri Vibrio dapat menyebabkan penyakit pada sistem pencernaan khususnya penyakit kolera yang menimbulkan diare. Pada infeksi yang akut/parah dapat menimbulkan muntah yang menyebabkan dehidrasi hingga meninggal (Mailoa dan Setha 2011).

Infeksi bakteri Salmonella dapat menyebabkan penyakit gastroenteritis yang menyerang sistem pencernaan sehingga menyebabkan muntah-muntah. Kontaminasi bakteri Salmonella pada hasil perikanan seringkali terjadi khususnya di Amerika, sehingga mereka memperketat pemeriksaan pengiriman hasil perikanan dengan menerapkan sistem block detention. Menurut Aulia et al, (2015) prevalensi kontaminasi bakteri Salmonella pada hasil perikanan berkisar 33\%.

\section{KESIMPULAN}

Terdapat kontaminasi bakteri Vibrio spp. dan Salmonella spp. pada hasil perikanan yang dijual di pasar tradisional kota Tarakan kuhusunya pada ikan bandeng dan ikan layang.

\section{UCAPAN TERIMA KASIH}

Universitas Borneo Tarakan yang telah memberikan bantuan melalui dana DIPA UBT. Para mahasiswa Nurlina, Rahman dan Dewi Ana Tongtolangi yang telah membantu dalam pengambilan sampel dan pengurusan administrasi.

\section{DAFTAR PUSTAKA}

Amiruddin R, Darniati R, Ismail. 2017. Isolasi dan identifikasi Salmonella sp. pada ayam bakar di rumah makan syiah kuala Kota Banda Aceh. Jurnal Ilmiah Mahasiswa Veteriner (JIMVET). 1(3): 265-274.

Asikin AN, Hutabarat S, Darmanto YS, Prayitno SB. 2014. Kandungan bakteri patogen pada udang windu (Penaeus monodon Fabricius) pascapanen asal tambak. Jurnal Dinamika Pertanian. 29(2): 199-206.

Ashofa EA, Sarjito, Prayitno SB. 2014. Identifikasi bakteri Vibrioyang berasosiasi dengan penyakit bakterial pada kepiting bakau (Scylla serrata) yang berasal dari Rembang. Journal of Aquaculture management and Technology. 3(2): 118125.

Aulia R, Handayani T, Yannie Y. 2015. Isolasi identifikasi dan enumerasi bakteri Salmonella spp. pada hasil perikanan serta resistensinya terhadap antibiotik. Jurnal Biologi Indonesia (BIOMA). 11(1): 15-33.

Austin B, Austin DA. 1989. Methods for the Micribiological Examination of Fish and Shellfish. Ellis Horwood Ltd. Chichester, England.

Dwiyitno. 2010. Identifikasi bakteri patogen pada produk perikanan dengan teknik molekuler. Squalen Bulletin of Marine and Fisheries Postharvest and Biotechnology. 5(2): 67-78.

Handayani DW, Diansyah G, Isnaini. 2020. Analisis koloni bakteri Vibrio sp. dan kualitas air pada air budi daya juwana kuda laut (Hippocampus sp). Maspari Journal: Marine Science Research. 12(1): 1-8.

Hidayat AR, Syarif. 2013. Karakterisasi bakteri genus Vibrio dan ikan kerapu (Plectropomus sp). Jurnal Ilmiah Biologi (BIOGENESIS). 1(2): 141-143.

Holt JG, Krieg NR, Sneath PHA, Staley JT, Williams ST. 1994. Bergey's Manual of Determinative Bacteriology. Ninth Edition. Sans Taghe.

Ihsan B, Retnaningrum E. 2017. Isolasi dan identifikasi bakteri Vibrio sp. pada kerang kapah (Meretrix meretrix) di Kabupaten Trenggalek. Jurnal Harpodon Borneo. 10(1): 23-27

Ihsan B, Retnaningrum E. 2020. The numerical phenetic of taxonomy Vibrio in shellfish (Meretrix meretrix) at edu-tourism mangrove cengkrong beach Trenggalek. Jurnal Ilmiah Perikanan dan Kelautan (JIPK). 12(2): 296-301.

Ihsan B, Abdiani IM, Imra. 2018. Deteksi dan identifikasi bakteri Salmonella spp. pada ikan bandeng yang dijual di pasar gusher Kota Tarakan. Jurnal Harpodon Borneo. 11(1): 46-51.

Mailoa MN, Setha B. 2011. Karakterisasi patogenitas Vibrio sp. diisolasi dari lendir sidat (Anguilla sp.). Molucca Medica. 4(1): 42-48. 
Rahmi E, Agustina D, Jamin F. 2014. Isolasi dan identifikasi genus Salmonella dan Shigella dari feses orang utan sumatera (Pongo abelii) di pusat reintroduksi orang utan Jantho. Jurnal Medika Veterinaria. 8(1): 5-8.

Rene KA, Dadie A, Ouastimohe, Karou T, Dje KM, Menan E. 2014. Serotypes and antibiotic resitance of Salmonella spp. isolated from poulty carcass and raw gizzard sold in markets and catering in Abdja, Côte D'ivoire. International Journal of Current Microbiology and Applied Sciences. 3(6): 764-772.
Suharni TT, Nastiti SJ, Soetarto AES. 2008. Mikrobiologi Umum. Yogyakarta (ID): Universitas Atma Jaya.

Suprayitno E. 2020. Kajian kesegaran ikan di pasar tradisional dan modern Kota Malang. Journal of Fisheries and Marine Research. 4(2): 289-295.

[SNI]. Standar Nasional Indonesia. 2006. Ikan Segar Bagian 2: Persyaratan Bahan Baku. ICS 67.120.30. SNI 01-2729-2006. Badan Standar Nasional.

[SNI]. Standar Nasional Indonesia. 2006. Cara Uji Mikrobiologi $V$ Tentang Penentuan Salmonella pada Produk Perikanan. SNI 01-2332.2-2006. Jakarta (ID): SNI. 